DOI: https://doi.org/10.47405/mjssh.v5i12.595

\begin{tabular}{|c|c|}
\hline & Malaysian Journal of Social Sciences and Humanities (MJSSH) \\
\hline Malaysian Journal of & Volume 5, Issue 12, December 2020 \\
\hline $\begin{array}{l}\text { Humantitis } \\
\text { (Ms-sSH) }\end{array}$ & e-ISSN : 2504-8562 \\
\hline & $\begin{array}{l}\text { Journal home page: } \\
\text { www.msocialsciences.com }\end{array}$ \\
\hline
\end{tabular}

\title{
Keperluan Pembangunan Industri Pertahanan Malaysia
}

\author{
Mohamed Fajil Abd. Batau1, Nazariah Osman', Mohamad Faisol Keling1 \\ ${ }^{1}$ College of Law, Government and International Studies, Universiti Utara Malaysia (UUM) \\ Correspondence: Mohamed Fajil Abd. Batau (fajil_batau@uitm.edu.my)
}

\begin{abstract}
Abstrak
Pembangunan keupayaan pertahanan merupakan salah satu agenda dalam Dasar Pertahanan Negara Malaysia (DPN), pelbagai strategi dirangka dan dilaksanakan bagi memantapkan kekuatan Angkatan Tentera Malaysia (ATM) khususnya. Salah satu komponen yang diberikan perhatian adalah membangunkan Industri Pertahanan Negara, malah pembangunannya memperlihatkan kepada keperluannya kepada keselamatan dan ekonomi negara. Prinsip pertahanan berdikari, keperluan kepada keselamatan negara dan juga pembangunan kepada ekonomi secara amnya menjadi pemangkin kepada pembangunan Industri Pertahanan (IP) ini. Secara keseluruhannya objektif dan matlamat pembangunan IP Malaysia yang bermula sekitar 1960an telah menjadi salah satu agenda utama kerajaan bagi keberlangsungan industri ini, malah sehingga ke hari ini usaha untuk memajukannya masih diberi perhatian oleh kerajaan bagi mencapai prinsip self-reliance yang selari dengan intipati di dalam Dasar Pertahanan Negara Malaysia. Artikel ini secara amnya akan membincangkan keperluan dalam pembangunan IP ini sejak awal penubuhannya.
\end{abstract}

Kata kunci: industri pertahanan, pertahanan berdikari, keselamatan negara, pembangunan ekonomi

\section{The Needs of Malaysia's Defense Industry Development}

\begin{abstract}
The development of defense capabilities is one of the agendas in the Malaysia National Defense Policy (NDP), various strategies are formulated and implemented to strengthen the defense system of the Malaysian Armed Force (MAF). One of the components that are given attention is the development of the National Defense Industry, in fact the development shows some of the needs for security and economic matters. The principles of self-reliance, the need for national security as well as development to the economy are the catalysts for the development of this Industry. Overall, the objectives and goals of the country's defense industry development which started around the 1960s have become a major government agenda for the sustainability of this industry. The efforts to develop the industry are still given an attention by the government to achieve the principle of self-reliance in line with the essence in the National Defense Policy of Malaysia. This article will generally discuss what are the needs for development of Malaysia's Defense Industry since the beginning of its establishment.
\end{abstract}

Keywords: Defense Industry, self-reliance, national security, economy development 


\section{Pengenalan}

Idea membangunkan industri pertahanan negara telah bermula sekitar tahun 1960an dengan usaha penubuhan Syarikat Malaysia Explosive Sdn. Bhd. (SME) yang merupakan pengeluar bahan letupan dan peluru senjata ringan bagi memenuhi keperluan ATM. Setelah itu Industri pertahanan Malaysia terus dikembangkan bagi mencapai prinsip pertahanan berdikari dalam membangunkan dan memodenkan ATM melalui aset pertahanan. Pelbagai usaha dan inisiatif diambil oleh kerajaan dalam pembangunan industri pertahanan negara ini. Justeru itu, sebanyak 5 sektor industri pertahanan telah difokuskan seperti sektor maritim, aeroangkasa, persenjataan, automotif dan komunikasi \& teknologi maklumat serta penubuhan beberapa agensi dan jabatan seperti Majlis Industri Pertahanan Malaysia (MIPM), Institut Penyelidikan Sains dan Teknologi Pertahanan (STRIDE), Bahagian Industri Pertahanan (BIP) dan Institut Pertahanan dan Keselamatan Malaysia (MIDAS) bagi membolehkan usaha pembangunan ini dilaksanakan mengikut kerangka IP Malaysia ${ }^{1}$. Selain itu juga usahama daripada sektor swasta iaitu pemain industri pertahanan yang utama seperti seperti Syarikat Malaysia Explosive (SME) Ordnance Sdn. Bhd, Defence Technology (DEFTECH), Boustead Naval Shipyard Sdn Bhd (BOUSTEAD), Syarikat AIROD, Syarikat Malaysia Mining Corporation (MMC) dan lainlain telah firma pertahanan memberikan impak kepada perkembangan industri pertahanan negara. Usaha kerajaan dalam membangunkan dan memperkembangkan IP negara signifikan kerana telah menjadi salah satu komponen dalam dokumen rasmi Dasar Pertahanan Negara Malaysia (DPN) dan terus diberikan perhatian bagi menyiapkan keupayaan pertahanan ATM dalam keadaan siap siaga. Malah pembangunan IP juga telah dipengaruhi dalam prinsip pertahanan berdikari "self-reliance" yang merupakan elemen utama dalam pembangunan DPN. Selain daripada menyediakan keperluan aset Pertahanan kepada ATM, kerajaan juga dilihat mempunyai beberapa matlamat lain dalam pembangunan IP negara yang penting bukan sahaja bagi tujuan keselamatan tetapi juga kepada keperluan yang lain.

\section{Keperluan Pembangunan Industri Pertahanan (IP) Negara Malaysia}

Dalam menjaga keselamatan dan kedaulatan sesebuah negara keperluan dalam pembangunan dasar pertahanan perlu diambil kira dalam menangani ancaman yang tertentu. Selain daripada pembangunan sumber manusia dalam angkatan tentera (Non-Material), perkara berkaitan bukan sumber manusia (material) perlu dibangunkan supaya mempunyai pembangunan keselamatan secara komprehensif. Salah satu komponen yang perlu dititikberatkan adalah pembangunan aset dan sistem pertahanan melalui proses IP negara. IP negara yang dibangunkan dapat memenuhi keperluan dan keupayaan keselamatan selain dapat memacu pembangunan ekonomi negara.

Rajah 1: Keperluan Pembangunan Industri Pertahanan Negara Malaysia

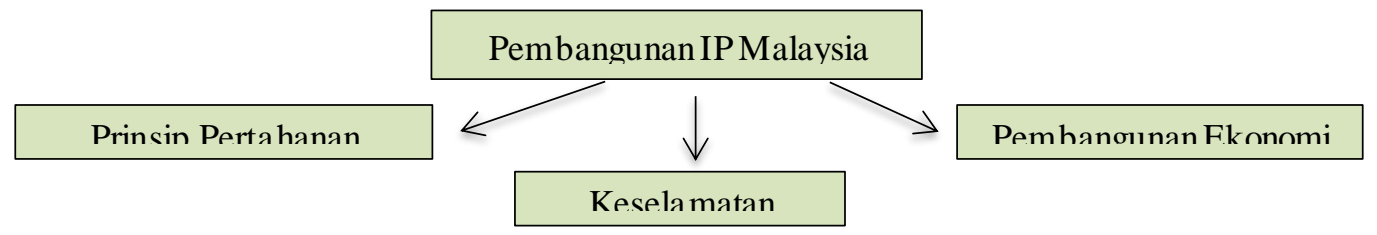

\section{Prinsip Pertahanan Berdikari}

Dalam dokumen rasmi DPN kerajaan Malaysia, prinsip self-reliance dalam konteks pertahanan atau pertahanan berdikari menjadi tunjang kepada pembangunan dan pemodenan ATM. DPN negara menghuraikan beberapa komponen dalam memantapkan strategi pertahanan ATM seperti kerjasama

\footnotetext{
${ }^{1}$ Ehsan Iskandar. (2008). STRIDE: 40 Tahun Memacu Penyelidikan Pertahanan Negara. Perajurit. Mei. Muka 45-49
} 
keselamatan serantau ${ }^{2}$, keselamatan menyeluruh, strategi pertahanan berdikari dan salah satu komponen yang menjadi topik perbincangan adalah pembangunan industri pertahanan negara, malah pada tahun 2020 dalam dokumen rasmi Kertas Putih Pertahanan Malaysia (KPP), IP merupakan salah satu industri strategik negara dalam pembangunan keupayaan pertahanan $\mathrm{ATM}^{3}$. Malah, pada tahun 2010 juga satu Blue Print/Dasar Industri Pertahanan telah digubal bagi usaha pembangunannya. IP negara ini adalah salah satu strategi kerajaan bagi memenuhi keperluan pembangunan ATM dari aspek logistik, aset dan sistem pertahanan ATM dengan mengurangkan kebergantungan dengan negara luar ${ }^{4}$. Selain itu, IP negara menjadi agenda utama kerajaan dalam mengurangkan kebergantungan dengan negara lain terutamanya melalui mengeluarkan, menyelenggarakan aset pertahanan ATM dan juga proses pemindahan teknologi pertahanan daripada industri luar negara. Kebanyakan negara cuba mengamalkan prinsip berdikari atau pertahanan berdikari dalam sektor keselamatan dan pertahanan, malah beberapa negara di Rantau Asia memfokuskan bajet pertahanan yang besar dalam memenuhi keupayaan pertahanan angakatan tentera ${ }^{5}$. Oleh demikian Malaysia melaksanakan usaha pembangunan IP negara melalui pelbagai kaedah dan strategi dalam bagi mencapai self-reliance dalam agenda memperkukuhkan agenda pertahanan. Kementerian Pertahanan Malaysia (KEMENTAH) menjadi tonggak utama dalam pembangunan IP ini dengan bantuan dan sokongan daripada pelbagai agensi, jabatan, sektor swasta yang berkaitan terutamanya pemain industri pertahanan tempatan malah kerjasama dengan negara luar juga tidak dipinggirkan. Kerajaan dengan pelbagai usaha telah membangunkan industri pertahanan negara bagi merealisasikan strategi prinsip pertahanan berdikari sebagaimana terkandung dalam $\mathrm{DPN}^{6}$.

Jika dilihat inisiatif kerajaan pada awalnya menjadi negara pengguna atau pembeli aset dan sistem pertahanan daripada negara luar bagi memenuhi keperluan dan keupayaan ATM di mana setiap pembelian perlulah disertai dengan pemindahan teknologi bagi mendapatkan kepakaran dalam industri ini. Pada awal pembangunan IP Malaysia kekurangan kepakaran tempatan dalam bidang sains dan teknologi pertahanan menjadi halangan utama, kepakaran merupakan salah satu sumber penting adalah bagi kemajuan dalam sesebuah IP negara. Selain itu, beberapa strategi dirangka oleh kerajaan bagi pemindahan kepakaran melalui proses kontrak pembelian daripada pengeksport aset pertahanan ini. Malah kerajaan juga pada awalnya menyatakan perolehan aset daripada negara luar akan meningkatkan usaha kerjasama dalam membangunkan IP tempatan dan dalam jangka masa panjang IP negara boleh berdikari dalam pengeluar aset pertahanan tempatan.

Keperluan untuk membangunkan IP secara berdikari adalah strategi kebanyakan negara yang ingin melihat keupayaan pertahanan dan keselamatan negara dibangunkan secara sendiri. Malah keperluan self-reliance perlulah bermula daripada komponen IP dimana keperluan aset pertahanan menjadi elemen penting dalam merangka strategi pertahanan mengikut doktrin ketenteraan yang ditetapkan oleh ATM itu sendiri ${ }^{7}$. Pelbagai ancaman tradisional dan bukan tradisional sejak dari perang dingin kepada keselamatan negara yang memerlukan sokongan sistem pertahanan yang maju supaya dapat menangani dan menggerakkan kemampuan ATM untuk bertahan serta melakukan tugas operasi ketenteraan. Prinsip pertahanan berdikari diadaptasikan dalam pembangunan IP negara dapat direalisasikan melalui penguasaan kepakaran, pembangunan dan penyelidikan daripada industri luar. Jika dilihat kemajuan negara jiran seperti Indonesia dan Singapura dalam industri ini dengan kemampuan mengeluarkan aset pertahanan tempatan yang boleh dikatakan maju malah dapat digunakan oleh angkatan ketenteraan negara tersebut (TNI, SAF). Prinsip untuk bertahan sendiri dapat

\footnotetext{
${ }^{2}$ Carlyle A. Thayer. (February 2007). The Five Power Defence Arrangements: The Quiet Achiever. Dipetik daripada la man www.regionalsecurity.org.au. Volume 3 Number 1.

${ }^{3}$ Kertas Putih Pertahanan, Kementerian Pertahanan Malaysia, 2019.hlm. 78 - 80

${ }^{4}$ Safeek Affendy Razali, 2019, STRIDE tingkat industri pertahanan negara, dipetik daripada laman sesawang https://www.bharian.com.my/berita/nasional/2019/10/61 8471/stride-tingkat-industripertahanan-negara

${ }^{5}$ Muthiah Alagapa (1990). Malaysia: From The Commonwealth Umbrella to Self Reliance. Dalam K.W Chin (ed). Defence Spending in Southeast Asia. Singa pore: ISEAS: 181-193.

${ }^{6}$ Mohamad Faisol Keling, Ahmad Shah Pakeer Mohamed \& Md Shukri Suhib (2016). "Dasar Pertahanan Negara Malaysia: Adakah ianya Kukuh?” in MIMBAR PENDIDIKAN: Jurnal Indonesia untuk Kajian Pendidikan, Vol.1(1) Maret, pp.101-122. Bandung, Indonesia: UPI Press.

${ }^{7}$ Nasibah Harun. (2002). Dasar Pertahanan Menyeluruh, Sempena Hari Angkatan Tentera Malaysia. Perajurit. Julai: hlm 17
} 
dilihat dalam pembangunan IP negara tersebut dimana kebergantungan kepada negara lain yang boleh menjadi ancaman dalam pelbagai bentuk. Idea utama dalam prinsip pertahanan berdikari adalah ATM mampu bersiap siaga dalam semua sumber pertahanan terutamanya program atau pembangunan IP negara dengan tidak bergantung kepada negara luar dalam pemerolehan aset pertahanan ATM. Kepentingan berdikari dalam pemerolehan dan kelengkapan aset pertahanan ATM serta aktiviti lain seperti Maintenance, repair, overhaul $(M R O)^{8}$ secara tempatan juga akan mampu mengekang ancaman serta menyediakan keupayaan pertahanan dalam keadaan konflik ataupun krisis ancaman dalam persekitaran antarabangsa yang tidak menentu.

\section{Keselamatan Negara}

Keselamatan negara adalah menjaga dan mengawal keselamatan di udara, darat mahupun laut secara komprehensif dengan pelbagai strategi pertahanan ketenteraan. Ianya adalah satu tindakan daripada pihak kerajaan melalui pasukan keselamatannya bagi melindungi rakyatnya dan kawasan kepentingannya daripada pelbagai ancaman yang tidak menentu9. Keselamatan Negara Malaysia telah digubal dan dilaksanakan melalui dokumen rasmi Dasar Keselamatan Negara dan juga Dasar Pertahanan Negara yang merangkumi pelbagai aspek keselamatan dan strategi pertahanan bagi mengekang sebarang ancaman ${ }^{10}$. Jika dilihat dalam perspektif Industri pertahanan bagaimana Industri ini mampu memberikan satu alat sokongan untuk menguatkan keupayaan keselamatan dan pertahanan terutamanya kepada pasukan keselamatan negara iaitu ATM. Negara yang berkecimpung dalam industri ini memfokuskan kepada pemantapan dan pemodenan pertahanan dalam aspek persenjataan, jika dilihat negara seperti Pakistan, Taiwan, Korea Utara mahupun negara jiran Indonesia dan Singapura contoh yang baik dalam membangunkan IP negara tersebut dalam menangani ancaman serta memperkembangkan keupayaan pertahanan negara khususnya. Sektor keselamatan akan menjadi mantap dalam sesebuah negara dengan adanya pembangunan industri pertahanan yang maju dan bukan sekadar menjadi negara pengguna ${ }^{11}$. IP negara dapat membantu menjaga keselamatan negara dengan pemerolehan aset dan aktiviti MRO yang dapat menyediakan semua cabang ATM dengan tahap kesediaannya yang tinggi bagi menangani ancaman di semua ruang atau sempadan negara ${ }^{12}$.

Pengeluaran dan pemerolehan Aset dan sistem pertahanan menjadi aktiviti utama industri pertahanan. Aktiviti seperti $M R O$ dalam semua sektor industri pertahanan Malaysia juga membolehkan aset ATM dapat diselenggarakan dan berada di dalam keadaan yang bersedia. Ini dapat dilihat fungsi IP negara dalam menyediakan sistem sokongan kepada pasukan keselamatan khususnya ATM. Seperti yang dapat dilihat pelbagai usaha kerajaan melalui Kementerian Pertahanan Malaysia (KEMENTAH) menyediakan keperluan logistik kepada ATM seperti pembelian dan penyelenggaraan kereta kebal, jet pejuang, kapal perang, senjata ringan malah sistem pertahanan seperti satelit pengawasan, alat kelengkapan dan sokongan ketenteraan bagi melaksanakan operasi pasukan ketenteraan. Usaha ini adalah peranan yang dimainkan oleh pemain industri pertahanan negara yang merupakan agen dalam penawaran kepada kerajaan malah ia sedikit sebanyak membantu kerajaan dalam menjaga keselamatan dan pertahanan negara. Syarikat dan pemain industri yang utama seperti DEFTECH, BOUSTEAD, AIROD, SUKHOI dan lain-lain menjadi sebahagian penyumbang kepada keselamatan negara. Selain itu juga dengan adanya industri ini, sedikit sebanyak menyediakan ruang kepada ATM dalam memodenkan keupayaan pertahanan yang mengikut keperluan semasa dengan kemajuan teknologi

\footnotetext{
${ }^{8}$ Bidang penyelenggaraan, pembaikan dan baik pulih (MRO) serta pembuatan dalam industripertahanan.

${ }^{9}$ Mohd Nooraimy Bin Musa (2009). Dasar Pertahanan Negara - Menganalisis Kemampuan Angkatan Tentera Malaysia Mendukung Dasar Tersebut Pada Era Globalisasi. Universiti Malaya: Fakulti Sastera Dan Sains Sosial. Hlm 29.

10 Kementerian Pertahanan Malaysia. Dasar Pertahanan Malaysia. Sumber diekses dari http://www.pmo.gov.my/dokumenattached/Dasar/Dasar_Pertahanan_Negara.pdf

${ }^{11}$ Perutusan YB Tan Sri Dato' Hj. Muhyiddin Bin Hj. Mohd. Yassin, Menteri Dalam Negeri,Tan Sri Dato' Hj. Muhyiddin Bin Hj. Mohd. Yassin. Dasar Keselamatan dan Ketenteraman Awam. Kementerian Da lam Negeri.2019.hlm iv

${ }^{12}$ Dipetik daripada keratan akhbar Berita Harian. (28 Mac 2020). DSA, NATSEC 2020 tangani isu kesela matan dunia: Mohamad Sabu
} 
yang maju. Beberapa pemimpin kerajaan mengatakan bahawa IP akan menjadi salah satu industri yang akan membawa kepada pembangunan keselamatan negara melalui pemerolehan, pemindahan, kerjasama dengan IP dari negara maju yang lain. Kemajuan sains dan teknologi pertahanan dalam proses IP akan memberikan impak yang tinggi kepada keselamatan negara, penggunaan dan aplikasi sistem dan aset pertahanan yang maju dan kehadapan akan mewujudkan satu tahap keselamatan yang tinggi. IP Malaysia diwujudkan bagi menangani ancaman dan juga memodenkan logistik ATM mengikut arus ancaman yang berbeza dan mencabar.

\section{Pembangunan Ekonomi}

Industri Pertahanan merupakan satu industri yang dibangunkan bukan sahaja memenuhi keperluan keselamatan negara malah ianya satu industri ketenteraan dan pertahanan yang merupakan pemacu perkembangan ekonomi yang signifikan kepada masyarakat di negara yang membangunkan industri strategi tersebut. Malah kesan limpahan ekonomi dari perusahaan ketenteraan ini memberi kesan kepada pelbagai pihak. Sebagai sebuah negara, Malaysia melalui kerjasama daripada pelbagai pihak berusaha mengembangkan industri pertahanan Malaysia yang maju dan kuat, serta berfungsi sebagai pemangkin ekonomi. IP juga merupakan aktiviti atau perusahaan berat yang memerlukan modal pelaburan yang besar dan komitmen secara serius, maka penghasilan, pembuatan dan aktiviti penyelenggaraan, modifikasi dan lain-lain perlulah memerlukan kepakaran yang maju ${ }^{13}$. Dalam membincangkan IP kepada keperluan ATM dan keselamatan negara, industri pertahanan dapat menyumbang kepada peluang pekerjaan kepada golongan tempatan, penciptaan, pemindahan teknologi, pelaburan langsung asing, teknologi dwi guna dan lain-lain lagi. Selain itu juga pulangan pelaburan yang tinggi dapat dijana melalui aktiviti ini dapat dilihat melalui pemain industri pertahanan tempatan sebahagian besarnya membuka ruang dan peluang dalam pembangunan ekonomi tempatan.

Jika dilihat penganjuran dan penyertaan pameran pertahanan seperti Langkawi International Maritime and Aerospace Exhibition (LIMA) dan Defence Services Asia (DSA) telah membuka peluang kepada pemain-pemain industri untuk memasarkan dan membina kerjasama dengan industri pertahanan daripada negara lain, jelas ini merupakan satu langkah kerajaan dalam memacu ekonomi melalui industri ini ${ }^{14}$. Selain itu juga, kerajaan juga berhasrat dengan meletakkan kepentingan IP tempatan dalam Kertas Putih Pertahanan (KPP) pada tahun 2020 dan ingin memajukan industri sebagai pemangkin kepada pemacu kepada ekonomi negara. ${ }^{15}$ Ini menunjukkan IP negara ini dapat memberi impak positif kepada ekonomi negara dengan akiviti-aktiviti perdagangan. Jika dilihat kepada IP Malaysia dalam perspektif ekonomi kebanyakan aset pertahanan ATM diimport daripada negara luar, usaha ini sebenarnya untuk mendapatkan kerjasama dengan industri maju dalam pemindahan teknologi ketenteraan. Malah dengan aktiviti ini, kebanyakan syarikat pertahanan tempatan dapat mendapat pulangan pelaburan sekaligus menyediakan peluang pekerjaan tempatan dan terus bertahan dalam sektor yang memerlukan pelaburan dan komitmen yang tinggi. Peluang yang signifikan apabila IP negara maju dengan pengeluaran aset pertahanan yang berskala ekonomi seperti aktiviti mengeksport dan mengkomersialkan kepada negara lain membantu keberlangsungan pemain industri pertahanan tempatan sekali gus pulangan kepada pembangunan ekonomi negara. IP negara juga bukan sahaja merangkumi pembuatan aset malah lebih daripada itu, aktiviti $M R O$ dalam semua sektor industri pertahanan juga akan memberikan impak kepada ekonomi khususnya. Sebagai contoh Syarikat AIROD, anak syarikat National Aerospace \& Defense Industries (NADI) ditubuhkan pada tahun 1976 dan menyediakan perkhidmatan MRO penerbangan bertaraf dunia di Malaysia bagi pesawat. Diperkuatkan lagi dengan kepakaran dan kecemerlangan teknikal lebih dari dua dekad. AIROD juga telah berubah dari pemain nasional menjadi jenama yang diiktiraf dalam industri $M R O$ penerbangan global, dengan telah memberikan perkhidmatan lebih daripada 78 pelanggan di seluruh dunia. Beberapa pemain industri pertahanan mega di sektor aeroangkasa seperti Syarikat Airod, Airod Techno Power (ATP), Airod Aerospace Technology Sdn Bhd (AAe), Aerospace Technology Systems

\footnotetext{
${ }^{13}$ Kogila Balakrishnan (2008). Defence Industrialisation in Malaysia: Development Challenges and the Revolution in Military Affairs. Security Challenges, vol. 4, no. 4 (Summer 2008), pp. 135-155

${ }^{14}$ Mejar Faridah Shuib, DSA dan LIMA Wa wasan Menjana Industri Pertahanan Nega ra, hlm. 21 -23.

${ }^{15}$ Liew Chin Tong, 2019, Industri Pertahanan Pemangkin Ekonomi Negara, diakses daripada laman sesawang https://www.sinarharian.com.my/article/2 1624/KHAS/Pendapat.
} 
Corp (ATSC) dan SME Aerospace (SMEA) yang menyediakan khidmat, Pembaikan \& Baik pulih, pengubahsuaian dan peningkatan enjin serta pembuatan bahagian aeroangkasa dan avionik. Pemain industri aeroangkasa pertahanan ini adalah kumpulan yang bernaung di bawah National Aerospace \& Defence Industries Sdn Bhd (Nadi), ianya merupakan usaha kerajaan dalam membangunkan industri pertahanan tempatan melalui kerjasama daripada syarikat-syarikat tempatan swasta, malah ianya merupakan satu kumpulan yang memfokuskan pembangunan industri pertahanan dalam sektor aeroangkasa pertahanan mahupun komersil ${ }^{16}$.

\section{Kesimpulan}

Industri Pertahanan Malaysia merupakan satu industri pada awalnya penubuhannya untuk memenuhi keperluan ATM khususnya dalam pemilikan aset dan penyelenggaraan pertahanan, kemudian ia menjadi salah satu industri strategik negara dalam memenuhi keperluan keselamatan dan pembangunan ekonomi negara. Keperluan untuk berdikari dalam bidang pertahanan menjadi pemangkin dalam pembangunan IP ini dengan pelbagai usaha diwujudkan, malah ia telah menjadi satu industri yang perlu diberikan keutamaan, ini kerana pelbagai dasar secara tidak langsung digubal oleh pihak kerajaan bagi mencapai hasrat industri pertahanan yang berdikari dan maju. Pelbagai persoalan tentang sejauh manakah tahap kemajuan industri pertahanan masih menjadi satu isu yang perlu diberi perhatian oleh pihak yang terlibat. Kepentingan dan keperluan industri pertahanan dalam sesebuah negara perlu diletakan sebagai agenda utama kerajaan jika dilihat dalam perspektif pertahanan dan keselamatan serta pada masa yang memberi kesan langsung kepada pembangunan ekonomi negara.

\section{Rujukan}

Carlyle A. Thayer. (February 2007). The Five Power Defence Arrangements: The Quiet Achiever, 3, 1. Ehsan Iskandar. (2008). STRIDE: 40 Tahun Memacu Penyelidikan Pertahanan Negara. Perajurit. Mei. Muka 45-49.

Kertas Putih Pertahanan, Kementerian Pertahanan Malaysia, 2019. hlm. 78 - 80

Kogila Balakrishnan (2008). Defence Industrialisation in Malaysia: Development Challenges and the Revolution in Military Affairs. Security Challenges, 4(4), 135-155.

Liew, C. T. (2019). Industri Pertahanan Pemangkin Ekonomi Negara, diakses daripada laman sesawang https://www.sinarharian.com.my/article/21624/KHAS/Pendapat.

Mejar Faridah Shuib, DSA dan LIMA Wawasan Menjana Industri Pertahanan Negara, hlm. 21-23.

Mohamad Faisol Keling, Ahmad Shah Pakeer Mohamed \& Md Shukri Suhib (2016). Dasar Pertahanan Negara Malaysia: Adakah ianya Kukuh?. MIMBAR PENDIDIKAN: Jurnal Indonesia untuk Kajian Pendidikan, 1(1), 101-122.

Mohd Nooraimy Musa (2009). Dasar Pertahanan Negara: Menganalisis Kemampuan Angkatan Tentera Malaysia Mendukung Dasar Tersebut Pada Era Globalisasi. Universiti Malaya: Fakulti Sastera Dan Sains Sosial.

Muthiah Alagapa (1990). Malaysia: From the Commonwealth Umbrella to Self-reliance. Dalam K.W Chin (ed). Defence Spending in Southeast Asia. Singapore: ISEAS: 181-193.

Nadi Malaysia (2020). Dipetik dari latar belakang syarikat, About Us, 2020, diakses daripada laman sesawang http://www.nadimalaysia.com/

Nasibah Harun. (2002). Dasar Pertahanan Menyeluruh, Sempena Hari Angkatan Tentera Malaysia. Perajurit.

Safeek Affendy Razali (2019). STRIDE tingkat industri pertahanan negara, dipetik daripada laman sesawang https://www.bharian.com.my/berita/nasional/2019/10/618471/stride-tingkat-industripertahanan-negara

\footnotetext{
${ }^{16}$ About Us, 2020, diakses daripada laman sesawang http://www.nadimalaysia.com/
} 